\title{
Assessing English Education Department Students' Competence in Translating Indonesian Text into English
}

\author{
Farida Repelita Waty Kembaren¹, Muhizar Muchtar², and \\ Tri Indah Kusumawati ${ }^{1}$ \\ ${ }^{1}$ Universitas Islam Negeri Sumatera Utara, Medan, Indonesia \\ ${ }^{2}$ Universitas Sumatera Utara, Medan, Indonesia
}

\section{Abstract}

Translation skill is important for students of English Education Department as in the future they will need the skill to translate their own scientific papers for international publication. However, to master the skills of translating texts, students should have enough understanding on both the language and the culture of languages (source and target language). This research aims to 1 ) identify the difficulty faced by the students when translating texts, and 2) measure students' ability in translating texts. The data

Corresponding Author:

Farida Repelita Waty Kembaren titaancha@gmail.com

Received: 1 July 2019

Accepted: 18 July 2019

Published: 31 July 2019

Publishing services provided by Knowledge

(c) Farida Repelita Waty Kembaren et al. This article is distributed under the terms of the Creative Commons

Attribution License, which

permits unrestricted use and redistribution provided that the original author and source are credited.

Selection and Peer-review unde the responsibility of the AICLL 2019 Conference Committee. were gained from the students' translation products. The subjects were 30 students of English Education Department in the State Islamic University of North Sumatra. The data collecting instrument was translation test where students translated English text into Indonesian. The findings indicate that students had difficulty in translating the English text into Indonesian especially in terms of accuracy and acceptability, but the students' translations were better in terms of readability. The difficulties in translating the English text into Indonesian were due to students' lack of understanding in applying the appropriate translation methods when translating the text. Moreover, the students also lack of ability in choosing the right words that will be the best equivalence in the target language. The findings also show that students had sufficient ability in translating text from English to Indonesian.

Keywords: assessment, translation competence, source language, students, target language

\section{Introduction}

Translation skill is one of the mandatory courses offered for the students of English Education Department at the State Islamic University of North Sumatra. This subject is given in two modules. In the first module, the students learn about the basic theory of translation while in the second module they focus on applying the theory into practice. The skills of translating text are important because they will have capability in translating scientific papers for international publication from Indonesian into English. Most of 
lecturers in the State Islamic University of North Sumatra have great articles to publish in the Scopus indexed journals. However, it is still hard to find the translator that can help them in translating their papers into English. Therefore, by studying translation theories and practice, the English Education Department students of the State Islamic University of North Sumatra will have not only an opportunity as English teachers, but also ability and chance to be translators, especially, the translators of scientific papers.

To be a good translator, every student in English Education Department of the State Islamic University of North Sumatra should understand the culture and the language of both texts (Indonesia and English). Moreover, most of translators learn to translate from their personal experience (Kembaren \& Muchtar, 2018). Thus, to achieve this goal, the students develop a translation agency that will allow them to apply the translation theory they have learned in the classroom. The students are assigned to find the clients that need their translation service. Even though the students have studied the translation theory and get enough practice in translation class, they need to improve the quality of their translation product in order to produce more accurate, readable, and acceptable translation product.

Realizing the importance of translation class for the English Education Students, this study aims to 1) identify the difficulty faced by the students when translating texts, and 2) measure students' ability in translating texts. The data were gained from the students' translation products. By understanding about the challenges that students might face in translating text and by analyzing students' translation product, it is expected that students will be able to focus on the skills that they lack of and improve their translation products.

\section{Literature Review}

According to Newmark (1988) "Translation is a craft consisting in the attempt to replace a written message statement in one language by the same message or statement in another language". Newmark emphasizes that translation is a process of rendering written message, from source language to target language without adding or reducing the message. According to Catford (1974), "Translation is the replacement of textual material in one language by equivalent textual material in another language". Catford states that the replacement of textual material from the source language into the target language should be equivalent. According to Nida and Taber "Translation consists of reproducing receptor language in the natural equivalent of the source language message, first in terms of meaning and second in terms of style" (Suryawinata, 2003). It means translators 
should find an appropriate message for the target language and should translate the text appropriately. Based on the definitions above, there are several words that can become the main focus to define "translation", namely: replace, rendering, equivalent. Thus, it can be understood that translation is not merely converting the source text into the target text, but there are several things to consider so that the message in the source text can be replaced and rendered appropriately and equivalently, and of course by following the correct language structure of the target text and considering the context and cultural matters of the target text.

That is why, in relating to cultures, Larson (1984) mentions that "The receptor audience will decode the translation in terms of his own culture and experience, not in terms of the culture and experience of the author and audience of the original document. The translator then must help the receptor audience understand the content and intent of the source document by translating both cultures in mind." Based on this explanation, it is understood that to help the target readers understanding new cultures, translators need to know both source and target language culture so that they can find the most equivalent items to translate the source text.

According to Newmark (1988), translation methods relate to whole texts while translation procedures are used for sentences and the smaller units of language. To analyze students' difficulty in translating text, the researchers try to see whether the students use appropriate methods in translating the source texts based on Newmark's translation methods. Newmark also proposes eight translation methods, namely; word-for-word translation, literal translation, faithful translation, semantic translation, adaptation, free translation, idiomatic translation, and communicative translation.

\section{Research Method}

The research is descriptive qualitative study (Miles, Huberman \& Saldana, 2014) and translation studies oriented to translation product (Toury, 1995). The data were gained from the students' translation products. The subjects were 30 students of English Education Department in the State Islamic University of North Sumatra. The data collecting instrument was translation test where students translated English text into Indonesian.

\section{Result and Discussion}

After analyzing the data, it can be seen that the students have difficulty in using appropriate translation procedures when translating texts from Indonesian into English. 
Following are some examples of students' translation products and the better version of translation.

TABLE 1: Example 1.

\section{Source Text}

Sampah merupakan suatu yang terbuang atau dibuang dari sumber hasil aktivitas manusia maupun alam yang belum memiliki nilai ekonomis.

\section{Target Text}

Waste is a waste or is discharged from the source of results human and natural activities that do not have economic value.

In the table above, it can be seen that student translates the source text by using word-for-word translation method. The words translated singly by their most common meanings, out of context, for example; Waste is a waste. The better translation for this text would be "Waste is something discharged and comes from human natural activities which does not have economic value".

\section{TABLE 2: Example 2.}

\section{Source Text}

Pengelolaan sampah adalah meliputi pengumpulan, pengangkutan, sampai dengan pemusnahan atau pengelolaan sampah sedemikian rupa sehingga tidak menjadi gangguan kesehatan masyarakat dan lingkungan hidup.

\section{Target Text}

Waste management is covering collection, transportation, up to destruction or management garbage in such a way that it does not become a health problem community and environment.

In the table above, it can also be seen that the student uses word-for-word translation method to translate the text above, out of context and grammatical structure, for example; "it does not become a health problem community and environment". A better version of this translation would be: "Waste management consists of collecting, transporting, and managing the waste in such a way that it does not become a health problem for the community and environment.".

TABLE 3: Example 3.

\section{Source Text}

Pengelolaan sampah merupakan cara yang efektif untuk memutuskan rantai penularan penyakit, dan juga untuk meningkatkan kesehatan keluarga dan masyarakat

\section{Target Text}

Waste management is an effective way to break the chain disease transmission, and also to improve family and community health.

In the table above, it can be seen that the student uses literal translation technique in translating the text because even though the grammatical constructions are converted to the nearest equivalent, the lexical words are still translated singly, out of context, for example; To break the chain disease transmission. A better version of this translation would be: "Waste management is an effective way to cut the infected diseases and also to improve the health of family and community." 
TABLE 4: Example 4.

\section{Source Text}

Bertambahnya penduduk di area perkotaan dan pedesaan akan bertambahnya sampah rumah tangga dilingkungan sekitarnya.

\section{Target Text}

Increased population in urban and rural areas will increasing household waste in the surrounding environment.

In the table above, it can be seen that the student is translating the text by using word-for-word translation method because the student made a grammatical error in the phrase, "Increased population in urban and rural areas will increasing" which should be written "will increase". A better version for this translation would be: "The increase in population in urban and rural areas will increase the household waste in the surrounding environment".

TABLE 5: Example 5.

\section{Source Text}

Masalah lingkungan telah menjadi perhatian secara khusus bagi pemerintah.

\section{Target Text}

Environmental problems have gone specifically for the government.

In this example, the student also translates the text by using word for word translation method, and did not translate the meaning correctly. A better translation for this text would be: "The environmental problems have become a special concern for the government."

\section{Conclusion}

It is concluded that students had difficulty in translating the English text into Indonesian especially in terms of accuracy and acceptability, but the students' translations were better in terms of readability. The difficulties in translating the English text into Indonesian were due to students' lack of understanding in applying the appropriate translation methods when translating the text. Moreover, the students also lack of ability in choosing the right words that will be the best equivalence in the target language. The findings also show that students had sufficient ability in translating text from English to Indonesian. Based on the findings, it is expected that the students should improve their understanding about translation methods and procedures so that they will be able to produce higher quality of translation product. 


\section{References}

[1] Catford, J. C. (1974). A Linguistic Theory of Translation. Oxford: Oxford University Press.

[2] Kembaren, F. R. W., \& Muchtar, M. (2018). Translation Agency Project as a Strategy in Teaching Translation Theory. In Proceedings of the 1st Annual International Conference on Language and Literature (pp. 153-160). Medan: Fakultas Sastra UISU.

[3] Larson, M. L. (1984). Meaning-Based Translation: A Guide to Cross - Language Equivalence. USA: University Press of America.

[4] Miles, M. B., Huberman, A. M., \& Saldana, J. (2014). Qualitative data analysis: A methods sourcebook. 3rd. Thousand Oaks, CA: Sage.

[5] Newmark, P. (1988). A Textbook of Translation Studies. Great Britain: Prentice Hall.

[6] Suryawinata, Z. D. S. H. (2003). Translation (Bahasa Teori \& Penuntun Praktis Menerjemahkan). Jakarta: Kanisius.

[7] Toury, G. (1995). Descriptive Translation Studies and Beyond. Amsterdam: John Benjamin. 